\title{
Coupling land surface and crop growth models for predicting evapotranspiration and carbon exchange in wheat-maize rotation croplands
}

\author{
H. Lei ${ }^{1}$, D. Yang ${ }^{1}$, E. Lokupitiya ${ }^{2}$, and Y. Shen ${ }^{3}$ \\ ${ }^{1}$ State Key Laboratory of Hydroscience and Engineering, Department of Hydraulic Engineering, Tsinghua University, \\ Beijing, 100084, China \\ ${ }^{2}$ Department of Atmosphere Science, Colorado State University, Fort Collins, CO 80523, USA \\ ${ }^{3}$ Key Laboratory of Agricultural Water Resources, Center for Agricultural Resources Research, Institute of Genetics and \\ Developmental Biology, Chinese Academy of Science, Shijiazhuang, Hebei, 050021, China
}

Received: 26 May 2010 - Published in Biogeosciences Discuss.: 2 July 2010

Revised: 2 October 2010 - Accepted: 25 October 2010 - Published: 29 October 2010

\begin{abstract}
The North China Plain is one of the key cropproducing regions in China. However, water resources in the area are limited. Accurate modeling of water consumption and crop production in response to the changing environment is important. To describe the two-way interactions among climate, irrigation, and crop growth better, the modified crop phenology and physiology scheme from the SiBcrop model was coupled with the second version of the Simple Biosphere model ( $\mathrm{SiB} 2)$ to simulate crop phenology, crop production, and evapotranspiration of winter wheat and summer maize, which are two of the main crops in the region. In the coupled model, the leaf area index (LAI) produced by the crop phenology and physiology scheme was used in estimating sub-hourly energy and carbon fluxes. Observations obtained from two typical eddy covariance sites located in this region were used to validate the model. The coupled model was able to accurately simulate carbon and energy fluxes, soil water content, biomass carbon, and crop yield, especially for latent heat flux and carbon flux. The LAI was also well simulated by the model. Therefore, the coupled model is capable of assessing the responses of water resources and crop production to the changes of future climate and irrigation schedules of this region.
\end{abstract}

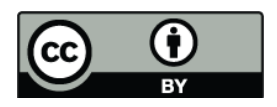

Correspondence to: D. Yang (yangdw@mail.tsinghua.edu.cn)

\section{Introduction}

The major crop production area in China is located in the northern regions, particularly in the Yellow River basin and the Haihe River basin. Northern China produces $59 \%$ of the national total crop production in 2008 (Ministry of Agriculture of China). Due to the semi-humid or arid climate, this region has limited water resources that amount to only $17 \%$ of the national total (Ministry of Water Resources of China). The problem between the large amount of water requirement for crop production and the limited availability of water resources is still an ongoing issue. In recent years, climate change (e.g., changes in precipitation, temperature, and $\mathrm{CO}_{2}$ concentration $\left.\left(\left[\mathrm{CO}_{2}\right]\right)\right)$ has drawn much attention on the potential impacts of this unresolved issue on future crop production. The effect of climate change and irrigation on crop production and water consumption is closely related with the food and water security of the nation. Thus, it is imperative for policy makers to address this concern.

Processes within the terrestrial ecosystem and atmosphere are intrinsically coupled. Environmental factors (e.g., water, temperature, and $\mathrm{CO}_{2}$ concentration) control vegetation dynamics. Changes in vegetation, in turn, influence on water, energy, and carbon fluxes. Interactions and feedback among climate, vegetation, and water have been significant concerns in recent years (Moorcroft, 2003; Kumar, 2007). Prescribing vegetation phenology in terms of known values (e.g., leaf area index, LAI) is the most common approach used by land surface models (Pitman, 2003). However, problems may be encountered if the model is set to make predictions because it does not describe a two-way feedback mechanism between

Published by Copernicus Publications on behalf of the European Geosciences Union. 
vegetation and the ambient environment. Even though a model can be used with the prescribed LAI, the LAI derived from the Normalized Difference Vegetation Index (NDVI) which is based on remotely sensed information, may not capture the remarkable dynamics of crops, thus, resulting in unsatisfactory magnitude and seasonality of carbon fluxes over croplands (Lokupitiya et al., 2009).

To date, many studies have coupled the vegetation dynamics model (crop growth model for agricultural ecosystem) with the land surface model for simulating water, energy, and carbon fluxes without prescribing vegetation phenology. Existing coupled models used for agricultural ecosystems are generally classified into three major classes, based on LAI calculation: (A) LAI calculation is based on carbon allocation. Net accumulated assimilation calculated by the land surface model is allocated to different carbon pools. LAI is then calculated from the accumulated carbon in the leaf carbon pool (Boegh et al., 2004; Wang et al., 2007; Ivanov et al., 2008). (B) LAI is directly calculated from bulk biomass, which is obtained from net assimilation calculated by the land surface model (Calvet et al., 1998). (C) LAI is calculated from observed meteorological variables (e.g., temperature) and simulated variables (e.g., evapotranspiration (ET), soil moisture, and soil temperature) from the land surface model (or the hydrological model) (Pauwels et al., 2007; Casanova and Judge, 2008; Maruyama and Kuwagata, 2010). The models in class $\mathrm{C}$ do not include carbon processes, limiting their application for changing atmospheric $\left[\mathrm{CO}_{2}\right]$. Although the models in class B include carbon simulation, production, and other components relevant to crops are not simulated, limiting their application for crop production studies. In the models in class A, simulation of crop production, LAI, water-energy flux, and carbon flux are included, which, in turn, allows for wide applicability and comprehensive evaluation of the model with observations.

Following the models in class A, the Simple Biosphere model version 2 (SiB2) (Sellers et al., 1996a, b) was coupled with the phenology and physiology scheme in the SiBcrop model (Lokupitiya et al., 2009) for simulating landatmosphere exchanges relevant to two typical crops (i.e., winter wheat and maize) in the North China Plain. Winter wheat and maize production in this region accounts for $80 \%$ and $83 \%$ of the nation's winter wheat and maize production, respectively (Ministry of Agriculture of China). The SiBcrop was developed to improve carbon flux simulation over croplands of soybean, maize, and wheat within the continental US (Lokupitiya et al., 2009); the behavior of this model remains unknown in other regions. Compared to the SiBcrop study, this study focuses on enabling the continuous modeling of ET and carbon flux in the North China Plain as well as its predictability in relation to climate change. Two EC sites with comprehensive observations were selected for evaluating model performance. Sensitivity analyses were also conducted to test the behavior of the model under different irrigation amounts and $\left[\mathrm{CO}_{2}\right]$.

\section{Description of the model}

The SiB2 (Sellers et al., 1996a, b) was coupled with the carbon allocation-based crop phenology and physiology scheme of the SiBcrop model (Lokupitiya et al., 2009). The SiBcrop model has been applied in an annual winter wheat (growing season: November to June) field and an annual corn (growing season: May to August) field in the US midwestern region. It resulted in a substantial improvement of the prediction of carbon exchange, compared with the original $\mathrm{SiB} 3$ which uses remotely-sensed NDVI as input (Lokupitiya et al., 2009). In the coupled model, the SiB2-based daily total photosynthetic carbon assimilation, daily average soil water content (SWC), and air temperature are used within the crop phenology and physiology scheme to calculate the daily LAI which influences energy, water, and carbon dioxide exchange between the land surface and the atmosphere. Crop growth was assumed to be unaffected by nutrient availability because sufficient fertilizers were applied by the farmers.

\subsection{Simple Biosphere model version 2}

The SiB2 is a widely used land surface model for modeling energy, water, momentum, and carbon dioxide exchange between the land surface and the atmosphere. Comprehensive measurements were observed in the evaluation of the model at a number of sites (e.g., Baker et al., 2003; Gao et al., 2004; Hanan et al., 2005). The SiB2 simulated leaf carbon assimilation with $\mathrm{C} 3$ or C4 photosynthetic models (Farquhar et al., 1980; Collotz et al., 1991). Transpiration (Tr) was linked with leaf carbon assimilation by a stomatal conductance model (Ball et al., 1987). Fluxes were simulated in the electrical analog form expressed by multiplying the potential difference (i.e., vapor pressure, temperature, and $\mathrm{CO}_{2}$ partial pressure gradients) with the conductance (i.e., aerodynamic, bare soil surface, and stomatal conductances). Heat transport in the soil was simulated by the force-restore model, which only simulates ground surface temperature and deep soil temperature. Further improvements to $\mathrm{SiB} 2$ in our study included the replacement of the soil hydrology model using the van Genuchten equation (Yang et al., 2000; Wang et al., 2009), modification of the soil water stress factor on photosynthesis and stomatal conductance through soil water availability (Eq. 5) (Colello et al., 1998), introduction of a soil respiration model (Denning et al., 1996), and modifying certain parameters to tally with $\mathrm{SiBcrop}$.

The input of the SiB2 consists of basic meteorological elements, such as downward short-wave radiation, downward long-wave radiation, relative humidity, air temperature, wind speed, air pressure, ambient $\left[\mathrm{CO}_{2}\right]$, and precipitation (and irrigation). In the $\mathrm{SiB} 2$, the world's land cover types were lumped into nine classes. The invariant properties of each class were assigned to values based on an extensive survey of ecological literature. The dynamics of vegetation were represented by variations in leaf area indexes (including total 
leaf area index $\left(L_{\mathrm{T}}\right)$ and green leaf area index), which were all derived from remote-sensing NDVI through the relationship between LAI and the fraction of photosynthetically active radiation (PAR) absorbed by the green vegetation canopy (FPAR) and the simple ratio $(\mathrm{SR}, \mathrm{SR}=(1+\mathrm{NDVI}) /(1-\mathrm{NDVI}))$ (Sellers et al., 1996b). The vegetation cover $\left(f_{\mathrm{V}}\right)$ is constant for each vegetation biome in the SiB2. To represent the dynamics of vegetation cover in row crops better, it is simply estimated from total leaf area index through Beer's law ( $f_{\mathrm{v}}=1-\exp \left(1-k L_{\mathrm{T}}\right)$, where $k$ is the extinction coefficient and is commonly equal to 0.5 ). The soil physical parameters were from the measured soil water retention curve.

\subsection{Crop phenology and physiology scheme based on the SiBcrop model}

Crop emergence and subsequent growth stages were set based on the accumulated growing degree days (GDD) (Lokupitiya et al., 2009). The growth rate during the initial seedling phase was determined by the amount of carbon stored in the seeds. Relevant further details could be found in Lokupitiya et al. (2009).

Because the planting dates were generally fixed, the planting dates of winter wheat and summer maize were artificially set as 10 October and 15 June, according to the general cropping system. Harvest dates were determined by the minimum of total requirement of GDD and the planting dates of the next crop. The total biomass carbon, which is based on the daily photosynthetic assimilation calculated by the SiB2, was allocated to each carbon pool (i.e., roots, leaves, stems, and products) based on the phenology and physiology scheme. The carbon allocation pattern of each carbon pool with GDD is important for biomass simulation. Due to the differences in climate and cropping patterns between the US midwestern region and the North China Plain, the relationships between daily carbon allocation fractions and GDD for winter wheat and summer maize in the SiBcrop were substituted with the observations under the condition of unlimited soil water from the North China Plain (Zhang et al., 2002; Qiao et al., 2002) (Fig. 1). Compared with the original allocation scheme of maize in the SiBcrop, the proposed scheme was similar but had a slightly higher allocation fraction of leaves. Allocation of carbon to vegetation components is closely tied to light, water, and phenological status. Arora and Boer (2005) proposed a carbon allocation scheme in response to light availability (expressed by LAI) and soil water availability in the root zone. As the impact of light availability has been implicitly included in the proposed carbon allocation pattern with GDD, we only introduced the effect of soil water availability on carbon allocation from the work of Arora and Boer (2005). This was based on the premise that it is advantageous for the plant to allocate carbon to the roots when soil moisture is limited, which is expressed as follows:
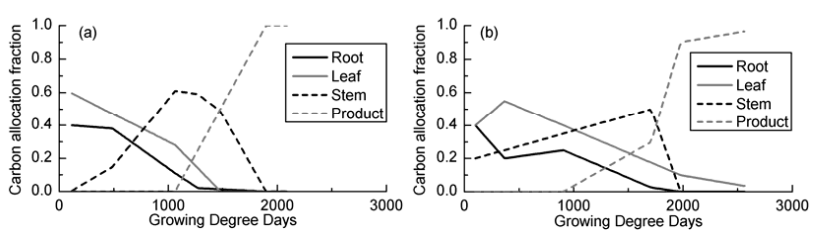

Fig. 1. Carbon allocation scheme under unlimited water conditions for (a) winter wheat and (b) summer maize.

$\alpha_{\mathrm{R}}=\frac{\varepsilon_{\mathrm{R}}+\omega(1-W)}{1+\omega(1-W)}$

$\alpha_{\mathrm{L}}=\frac{\varepsilon_{\mathrm{L}}}{1+\omega(1-W)}$

$\alpha_{\mathrm{S}}=\frac{\varepsilon_{\mathrm{S}}}{1+\omega(1-W)}$

$\alpha_{\mathrm{P}}=\frac{\varepsilon_{\mathrm{P}}}{1+\omega(1-W)}=1-\alpha_{\mathrm{R}}-\alpha_{\mathrm{L}}-\alpha_{\mathrm{S}}$

where $\alpha_{\mathrm{R}}, \alpha_{\mathrm{L}}, \alpha_{\mathrm{S}}$, and $\alpha_{\mathrm{P}}$ are the revised carbon allocation fractions for roots, leaves, stems, and products, respectively; $\varepsilon_{\mathrm{R}}, \varepsilon_{\mathrm{L}}, \varepsilon_{\mathrm{S}}$, and $\varepsilon_{\mathrm{P}}$ are the carbon allocation fractions under unlimited water conditions for roots, leaves, stems, and products, respectively; $\omega$ is set to be 0.8 for crops (Arora and Boer, 2005); and $W$ is the water availability in the root zone measured by:

$W=\max \left[0, \min \left(1, \frac{\theta-\theta_{\mathrm{r}}}{\theta^{*}-\theta_{\mathrm{r}}}\right)\right]$

where, $\theta$ is the volumetric soil water content in the root-zone, $\theta^{*}$ and $\theta_{\mathrm{r}}$ are the threshold of incipient soil water stress and wilting point (see Table 1), respectively.

At the end of each day, the carbon in each pool was estimated by subtracting the growth and maintenance respiration from the daily biomass carbon allocation of each pool. Cumulative carbon in the leaf pool was then used to calculate the daily LAI, following the details given in Lokupitiya et al. (2009). Parameters used in the coupled model corresponded to the default values in SiB2 and the SiBcrop models. Certain parameters were specific to the particular sites (Table 1).

\section{Study area and measurements}

The performance of the coupled model was evaluated by comparing the observations and simulations at two EC flux tower sites in the North China Plain: the Weishan site and the Luancheng site. Both sites had irrigated winter wheat and rain-fed summer maize (irrigated in dry years), which were cultivated in rotation and typical in this region. The growing season of winter wheat is usually from October to June (dry season), and the growing season of summer maize is usually from June to October (rainy season). Comparing to the study 
Table 1. Site specific parameters used in the coupled model.

\begin{tabular}{lllll}
\hline Symbol & Parameter & \multicolumn{2}{c}{ Value } & Source \\
\hline- & - & Weishan & Luancheng & - \\
$\theta^{*}$ & Threshold of incipient soil & 0.22 & 0.22 & Shen et al., 2002 \\
& water stress $\left(\mathrm{m}^{3} \mathrm{~m}^{-3}\right)$ & & & \\
$\theta_{r}$ & Wilting point $\left(\mathrm{m}^{3} \mathrm{~m}^{-3}\right)$ & 0.12 & 0.13 & measured \\
$\alpha$ & van Genuchten parameter $\left(\mathrm{cm}^{-1}\right)$ & 0.00483 & 0.0098 & measured \\
$n$ & van Genuchten parameter & 1.99 & 2.18 & measured \\
\hline
\end{tabular}

of Lokupitiya et al. (2009), the growing season of wheat was similar while the growing season of maize was postponed for approximate one month.

The Weishan site $\left(116^{\circ} 3^{\prime} \mathrm{E}, 36^{\circ} 39^{\prime} \mathrm{N}, 30 \mathrm{~m}\right.$ a.s.l. $)$ is located in the central North China Plain. The mean annual precipitation at the site was $553 \mathrm{~mm}$, and mean annual air temperature was $13.8^{\circ} \mathrm{C}$. Mean annual pan $(\Phi 20 \mathrm{~cm})$ evaporation was $1950 \mathrm{~mm}$. The groundwater table level ranged from 1.0 to $3.5 \mathrm{~m}$ within one year. The measurements consisted of meteorological measurements (i.e., precipitation, air temperature, relative humidity, wind speed, shortwave, longwave, and net radiation $\left.\left(R_{\mathrm{n}}\right)\right)$, EC measurements (i.e., latent heat $(L E)$ and sensible heat fluxes $\left(H_{\mathrm{S}}\right)$, carbon dioxide exchange), underground measurements (i.e., soil heat flux $(G)$, soil temperature and moisture content profile), and LAI measurement (Table 2, see Lei and Yang, 2010a for details). As for the carbon flux, the observed net ecosystem exchange (NEE) was separated into the gross primary production (GPP) and ecosystem respiration (Lei and Yang, 2010b) for direct comparison with the simulated GPP. A Large Aperture Scintillometer (LAS) was installed, and the flux tower is in the middle of its path. A previous study showed that there was a satisfactory agreement between the sensible heat fluxes observed by LAS and EC technique at this relatively homogeneous landscape, indicating the high reliability of the sensible heat flux measurement (Yang et al., 2010). The observed sensible heat flux by the EC technique will be used for evaluating the model. The Luancheng site is located to the northwest of the Weishan site $\left(114^{\circ} 41^{\prime} \mathrm{E}, 37^{\circ} 53^{\prime} \mathrm{N}\right.$, $50 \mathrm{~m}$ a.s.l.). Mean annual precipitation was $485 \mathrm{~mm}$, and mean annual air temperature was $12.8^{\circ} \mathrm{C}$. Mean annual pan $(\Phi 20 \mathrm{~cm})$ evaporation was $1616 \mathrm{~mm}$. The groundwater table level was deeper than $30 \mathrm{~m}$ because of large groundwater withdrawals for irrigation. Measurements and instruments used were similar to those at the Weishan site. These are summarized in Table 2. Eddy covariance fluxes were adjusted for variations in air density due to the transfer of water vapor and sensible heat (Webb et al., 1980). Meteorological data, including air temperature, relative humidity, wind speed, and precipitation, were obtained from the national standard weather station at the site.
At both sites, LAI was estimated by measuring randomly sampled leaf areas from the field. Each sample included about ten plants of wheat or three plants of maize. The leaf area was measured using the area meter. Plant density was simultaneously recorded. Normally, LAI was measured biweekly at the Weishan site, and once a week at the Luancheng site. At the Weishan site, LAI was non-destructively measured using the LAI-2000 plant canopy analyzer, starting from the maize season in 2008. In addition, dry weights of leaves, stems, and products (a plant other than root, leaf, and stem) at the Luancheng site were measured once a week. Two NDVI datasets, including eight-day $/ 250 \mathrm{~m}$ resolutions and monthly $/ 1 \mathrm{~km}$ resolution products, were obtained from the MODIS/Terra and used with algorithms in Sellers et al. (1996b) for deriving LAI, for comparison against the LAI produced by the coupled model. A filter was used as the noise-reduction technique to reduce noise in the NDVI time series (Velleman, 1980).

\section{Model running}

Vegetation type 9 (i.e., agriculture or C3 grassland) in the $\mathrm{SiB} 2$ and vegetation type 6 (i.e., $\mathrm{C} 4$ groundcover) were chosen to represent wheat and maize, respectively. Due to data availability, the simulation period at the Luancheng site was from 1 October 2007 to 30 September 2008. The period included one whole winter wheat season and one whole summer maize season. Hourly observed energy, water, and carbon dioxide fluxes, LAI, and dry biomass were compared with the values predicted by the model. The simulation period at the Weishan site was from 1 June 2005 to 8 June 2009. The period included four winter wheat seasons and four summer maize seasons. Half-hourly observed energy, water, and carbon dioxide fluxes, and LAI were compared with values predicted by the model. Surface fluxes and soil water content were calculated half-hourly (for the Weishan site) or hourly (for the Luancheng site), and the crop phenology and physiology scheme was calculated once a day. Two commonly used statistics (i.e., coefficient of determination $\left(R^{2}\right)$ for linear regression and root mean square error (RMSE)) were used to evaluate the model. 
Table 2. Summaries of the measurements and instruments.

\begin{tabular}{|c|c|c|c|}
\hline Site & Observation items & Instruments & Height or depth \\
\hline \multirow[t]{8}{*}{ Weishan } & $\begin{array}{l}\text { Sensible and latent heat fluxes and } \\
\text { carbon dioxide flux }\end{array}$ & $\begin{array}{l}\text { CSAT3, Campbell Scientific, Inc., Logan, } \\
\text { UT, USA and LI7500, LI-COR, Inc., } \\
\text { Lincoln, NE, USA }\end{array}$ & $3.7 \mathrm{~m}$ \\
\hline & $\begin{array}{l}\text { Downward (upward) shortwave } \\
\text { (longwave) radiation }\end{array}$ & $\begin{array}{l}\text { CNR-1, Kipp \& Zonen, Delft, The } \\
\text { Netherlands }\end{array}$ & $3.5 \mathrm{~m}$ \\
\hline & Soil heat flux & $\begin{array}{l}\text { HFP01SC, Hukseflux, Delft, The } \\
\text { Netherlands }\end{array}$ & $-0.03 \mathrm{~m}$ \\
\hline & Soil water content & TRIME-EZ/IT, IMKO, Ettlingen, Germany & $\begin{array}{l}-0.05,-0.1,-0.2,-0.4 \\
-0.8, \text { and }-1.6 \mathrm{~m}\end{array}$ \\
\hline & Soil temperature & $\begin{array}{l}\text { Campbell-107, Campbell Scientific Inc., } \\
\text { Logan, UT, USA }\end{array}$ & $\begin{array}{l}-0.05,-0.1,-0.2,-0.4 \\
-0.8, \text { and }-1.6 \mathrm{~m}\end{array}$ \\
\hline & Air temperature and relative humidity & HMP45C, Vaisala Inc., Helsinki, Finland & $3.6 \mathrm{~m}$ \\
\hline & Wind speed & $\begin{array}{l}\text { 05103, Young Co., } 120 \text { Traverse City, MI, } \\
\text { USA }\end{array}$ & $10.0 \mathrm{~m}$ \\
\hline & Precipitation & $\begin{array}{l}\text { TE525MM, Campbell Scientific Inc., } 121 \\
\text { Logan, UT, USA }\end{array}$ & $1.5 \mathrm{~m}$ \\
\hline \multirow[t]{6}{*}{ Luancheng } & $\begin{array}{l}\text { Sensible and latent heat fluxes and } \\
\text { carbon dioxide flux }\end{array}$ & $\begin{array}{l}\text { CSAT3, Campbell Scientific, Inc., Logan, } \\
\text { UT, USA and LI7500, LI-COR, Inc., Lin- } \\
\text { coln, NE, USA }\end{array}$ & $3.3 \mathrm{~m}$ \\
\hline & $\begin{array}{l}\text { Downward (upward) shortwave } \\
\text { (longwave) radiation }\end{array}$ & $\begin{array}{l}\text { CNR-1, Kipp \& Zonen, Delft, The } \\
\text { Netherlands }\end{array}$ & $3.0 \mathrm{~m}$ \\
\hline & Soil heat flux & HFP01, Hukseflux, Delft, The Netherlands & $-0.02 \mathrm{~m}$ \\
\hline & Soil water content & $\begin{array}{l}\text { Neutron probe (IH-II, Institute of } \\
\text { Hydrology, Wallingfoad, UK) }\end{array}$ & $\begin{array}{l}-0.1,-0.4,-0.6 \\
\text { and }-1.0 \mathrm{~m}\end{array}$ \\
\hline & Soil temperature & $\begin{array}{l}\text { 105T, Campbell Scientific Inc., Logan, UT, } \\
\text { USA }\end{array}$ & $\begin{array}{l}-0.02,-0.05,-0.1,-0.2 \text {, } \\
\text { and }-0.5 \mathrm{~m}\end{array}$ \\
\hline & $\begin{array}{l}\text { Air temperature, relative humidity, } \\
\text { wind speed, and precipitation }\end{array}$ & Chinese Meteorological Administration & $\begin{array}{l}1.5 \mathrm{~m} \text { for air temperature } \\
\text { and } 10.0 \mathrm{~m} \text { for wind speed }\end{array}$ \\
\hline
\end{tabular}

Once the coupled model was validated for present conditions, we tested the ability of the model to simulate the crop yield and ET in different irrigation and $\left[\mathrm{CO}_{2}\right]$ situations. In Sect. 5.3, a sensitivity study is presented concerning over the impact of the irrigation amount, but not of irrigation strategies. We chose the Luancheng site as case study, and the 2007-2008 wheat season was selected because there was no irrigation in the 2008 maize season. In this season, accumulated precipitation was $197 \mathrm{~mm}$ (mean seasonal precipitation was $130 \mathrm{~mm}$ ) with an exceedance probability of about
$11 \%$ (Sun et al., 2009), indicating that the season was relatively wet. Therefore, irrigation was implemented once with $122 \mathrm{~mm}$ in 4 April 2008, which was in the jointing stage of wheat. In Sect. 5.4, a sensitivity analysis was made with values of $\left[\mathrm{CO}_{2}\right]$ corresponding to $3 \times 381,2 \times 381$, and $381 \mathrm{ppm}$ (i.e., the current level) at the Luancheng site from October 2007 to September 2008, assuming that other climate forcing data (e.g., air temperature) were kept as the same as the current situation. We wish to point out that our model only considered the responses of photosynthesis and leaf conductance 


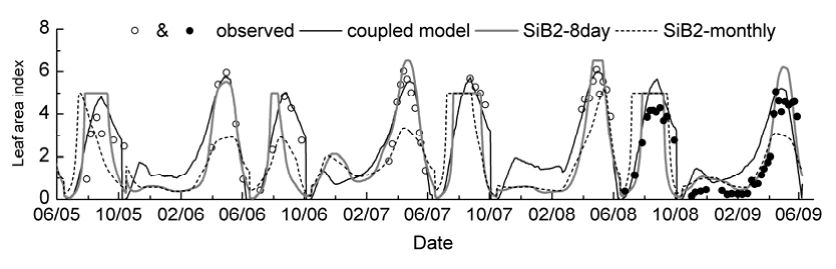

Fig. 2. Simulated and observed leaf area index (LAI) at the Weishan site. The SiB2-8day was derived from eight-day NDVI, and SiB2-monthly was derived from monthly NDVI. The hollow circles denote the observations from leaf area meter, and the solid circles denote the observations from the LI-2000.
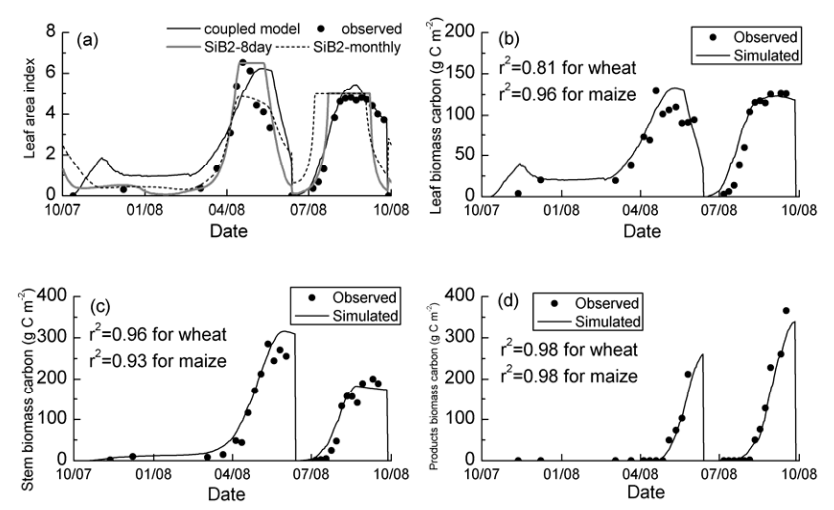

Fig. 3. Simulated and observed (a) leaf area index (LAI) and (bd) biomass carbon of different pools at the Luancheng site. $r^{2}$ is square of the Pearson product-moment correlation coefficient. In (a), the SiB2-8day was derived from eight-day NDVI and SiB2monthly was derived from monthly NDVI.

to increased $\left[\mathrm{CO}_{2}\right]$, but was not able to simulate the response of carbon allocation to $\mathrm{CO}_{2}$ enrichment because its underlying mechanism was not yet fully understood (Monje and Bugbee, 1998; Niklaus et al., 2001; Suter et al., 2002).

\section{Results and discussion}

\subsection{Validation of the crop growth simulation}

For comparison with the observed LAI, eight-day and monthly satellite-based LAI values were interpolated linearly to the daily values. The daily simulated and satellite-based LAI values in the days when measured LAI was available were selected. The coupled model was able to closely simulate LAI and biomass carbon, comparing to the observations at the two sites. The interannual variation of LAI was well simulated by the model (Figs. 2 and 3a). In contrast, the MODIS NDVI-based LAI was unsatifactory in reflecting the interannual variability of LAI, because it was saturated by its maximum values in the algorithms. The seasonal variability of wheat LAI was well simulated by both the eight-day
Table 3. Results of the comparisons of simulated and observed LAI. SiB2-8day was derived from eight-day NDVI and the SiB2-monthly was derived from monthly NDVI.

\begin{tabular}{llrr}
\hline Site & \multicolumn{1}{c}{ period } & $R^{2}$ & RMSE \\
\hline Weishan & \multicolumn{3}{c}{ Wheat season } \\
\cline { 2 - 4 } & Coupled model & 0.80 & 0.98 \\
& SiB2-8day & 0.87 & 0.83 \\
& SiB2-monthly & 0.78 & 1.36 \\
\cline { 2 - 4 } & \multicolumn{3}{c}{ Maize season } \\
\cline { 2 - 4 } & Coupled model & 0.77 & 0.97 \\
& SiB2-8day & 0.63 & 1.31 \\
& SiB2-monthly & 0.36 & 1.59 \\
\hline \multirow{3}{*}{ Wuancheng Wheat season } \\
\cline { 2 - 4 } & Coupled model & 0.75 & 1.35 \\
& SiB2-8day & 0.92 & 1.00 \\
& SiB2-monthly & 0.87 & 0.98 \\
\cline { 2 - 4 } & \multicolumn{3}{c}{ Maize season } \\
\cline { 2 - 4 } & Coupled model & 0.84 & 0.96 \\
& SiB2-8day & 0.75 & 1.21 \\
& SiB2-monthly & 0.43 & 1.70 \\
\hline
\end{tabular}

NDVI and the coupled model, which resulted in high $R^{2}$ and low RMSE (Table 3). However, the seasonal variability of maize LAI was unsatisfactorily simulated by NDVI, but was much better simulated by the coupled model (Table 3 ). These were essentially due to the fact that either NDVI or SR is generally insensitive to LAI when it exceeds a certain value (Gitelson et al., 2003; Sellers et al., 1996). The $1 \mathrm{~km} /$ monthly NDVI-based LAI had much lower peak value and was worse synchronous with the observed LAI (Fig. 2). This could be attributed to the interpolation scheme from monthly to daily values. Note that the predicted LAI by the model was much higher than the observed LAI in the 2008 maize season and the 2008-2009 wheat season, which could be attributed to the under-measurement of LAI by LAI-2000 in row crops due to sampling (Wilhelm et al., 2000).

By converting the measured dry biomass to biomass carbon (by multiplying 0.45 for the product and 0.5 for the stem and leaf), we compared the simulated and observed carbon biomass for different pools at the Luancheng site (Fig. 3). The simulations and measurements agreed quite well over the entire growing season for both wheat and maize. The square of the Pearson product-moment correlation coefficient $\left(r^{2}\right)$ ranged from 0.81 to 0.98 . The simulated ratio of root biomass to above-ground biomass was 0.14 and 0.08 for wheat and maize, respectively. These values were acceptable compared to the common values $(0.15-0.20$ for wheat and $0.10-0.15$ for maize) in this region (Mo et al., 2005). 
Table 4. Statistics for the comparisons against half-hourly observations at the Weishan site and hourly observations at the Luancheng site.

\begin{tabular}{|c|c|c|c|c|}
\hline Variables & Site & Crop season & RMSE & $R^{2}$ \\
\hline \multirow[t]{4}{*}{ Net radiation $\left(\mathrm{W} \mathrm{m}^{-2}\right)$} & \multirow[t]{2}{*}{ Weishan } & Maize & 14.5 & 0.99 \\
\hline & & Wheat & 14.5 & 1.0 \\
\hline & \multirow[t]{2}{*}{ Luancheng } & Maize & 17.4 & 1.0 \\
\hline & & Wheat & 18.7 & 1.0 \\
\hline \multirow[t]{4}{*}{ Latent heat flux $\left(\mathrm{W} \mathrm{m}^{-2}\right)$} & \multirow[t]{2}{*}{ Weishan } & Maize & 69.90 & 0.72 \\
\hline & & Wheat & 40.80 & 0.83 \\
\hline & \multirow[t]{2}{*}{ Luancheng } & Maize & 45.50 & 0.84 \\
\hline & & Wheat & 35.6 & 0.85 \\
\hline \multirow[t]{4}{*}{ Sensible heat flux $\left(\mathrm{W} \mathrm{m}^{-2}\right)$} & \multirow[t]{2}{*}{ Weishan } & Maize & 38.29 & 0.58 \\
\hline & & Wheat & 39.8 & 0.63 \\
\hline & \multirow[t]{2}{*}{ Luancheng } & Maize & 30.18 & 0.68 \\
\hline & & Wheat & 32.64 & 0.57 \\
\hline \multirow{4}{*}{$\begin{array}{l}\text { Net ecosystem exchange } \\
\left(\mu \mathrm{mol} \mathrm{m} \mathrm{m}^{-2} \mathrm{~s}^{-1}\right)\end{array}$} & \multirow[t]{2}{*}{ Weishan } & Maize & 4.62 & 0.85 \\
\hline & & Wheat & 4.05 & 0.79 \\
\hline & \multirow[t]{2}{*}{ Luancheng } & Maize & 5.58 & 0.82 \\
\hline & & Wheat & 4.73 & 0.78 \\
\hline
\end{tabular}

\subsection{Validation of the surface fluxes simulation}

The seasonal variations in the simulated and observed values of energy fluxes $\left(R_{\mathrm{n}}, L E, H_{\mathrm{S}}\right.$, and $\left.G\right)$, NEE, and SWC for the Weishan and Luancheng sites are shown in Figs. 4 and 5, respectively. Table 4 lists the statistics of the comparisons. For both sites, the seasonal variation in surface fluxes and SWC showed good agreement between the simulated and observed values. The $R_{\mathrm{n}}$ simulation had the highest $R^{2}$ and lowest RMSE. Simulated NEE and $L E$ had the second highest $R^{2}$. Overall, the $R^{2}$ of NEE and $L E$ were all greater than 0.7 in the entire seasons, which indicated that the model could explain more than $70 \%$ of the variability in the observed latent and carbon dioxide fluxes. The results suggest that the model is sound in simulating latent heat and carbon fluxes in this region. The simulation of carbon flux can also be confirmed by the comparison of the simulated GPP and observationderived GPP at the Weishan site (Fig. 6), which excluded the influence of soil respiration modeling. The simulated latent heat flux was larger than the observation during the summer maize seasons at the Weishan site (Fig. 4b). The observed soil evaporation data revealed that soil evaporation was significantly over-predicted (data not shown). Maize has lower vegetation cover than wheat, and thus the effect of overprediction of soil evaporation is more significant in the maize season than in the wheat season. Another possible reason for the over-prediction may be the under-measurement of the latent heat flux. The slope of the linear regression between $\left(R_{\mathrm{n}}-G\right)$ and $\left(L E+H_{\mathrm{S}}\right)$ was 0.75 and 0.87 for the Weishan (half-hourly data) and Luancheng (hourly data) sites, respec- tively. At the Luancheng site, the simulated seasonal soil evaporation total accounted for $32 \%$ of the simulated seasonal ET total in the wheat season, and the ratio of simulated seasonal total soil evaporation of simulated seasonal total ET was $35 \%$ for the maize season. The ratios were acceptable but higher, comparing to the observed values of $29.7 \%$ for wheat seasons and $30.3 \%$ for maize seasons at the Luancheng site averaged from 1995 to 2000 (Liu et al., 2002). Relatively high RMSE and low $R^{2}$ were found for the sensible heat flux. The comparison of the simulated ground heat flux and observed soil heat flux at a certain depth revealed that the magnitude of soil heat flux was well captured by the model (Fig. 4d and Fig. 5d). The seasonal variation in simulated ground heat flux was asynchronous with the observed soil heat flux, which was due to the mismatch between the simulated ground heat flux and measured soil heat flux at a certain depth (Shao et al., 2008).

\subsection{Comparison with the original SiB2}

For comparison, the results for LE and NEE simulated by the original SiB2 given eight-day and monthly NDVI as input were compared with the results of the coupled model, respectively. The $R^{2}$, RMSE and slope of linear regression $(\beta)$ values for the overall comparisons were listed in Table 5. For NEE, the coupled model is the most accurate, whereas the SiB2 with a monthly NDVI is the least accurate. This was similar to the work of Lokupitiya et al. (2009). However, there were no significant differences among the results for LE in the overall comparison. Figure 7 shows the daily course of midday-averaged LE at a selected period. Although the 

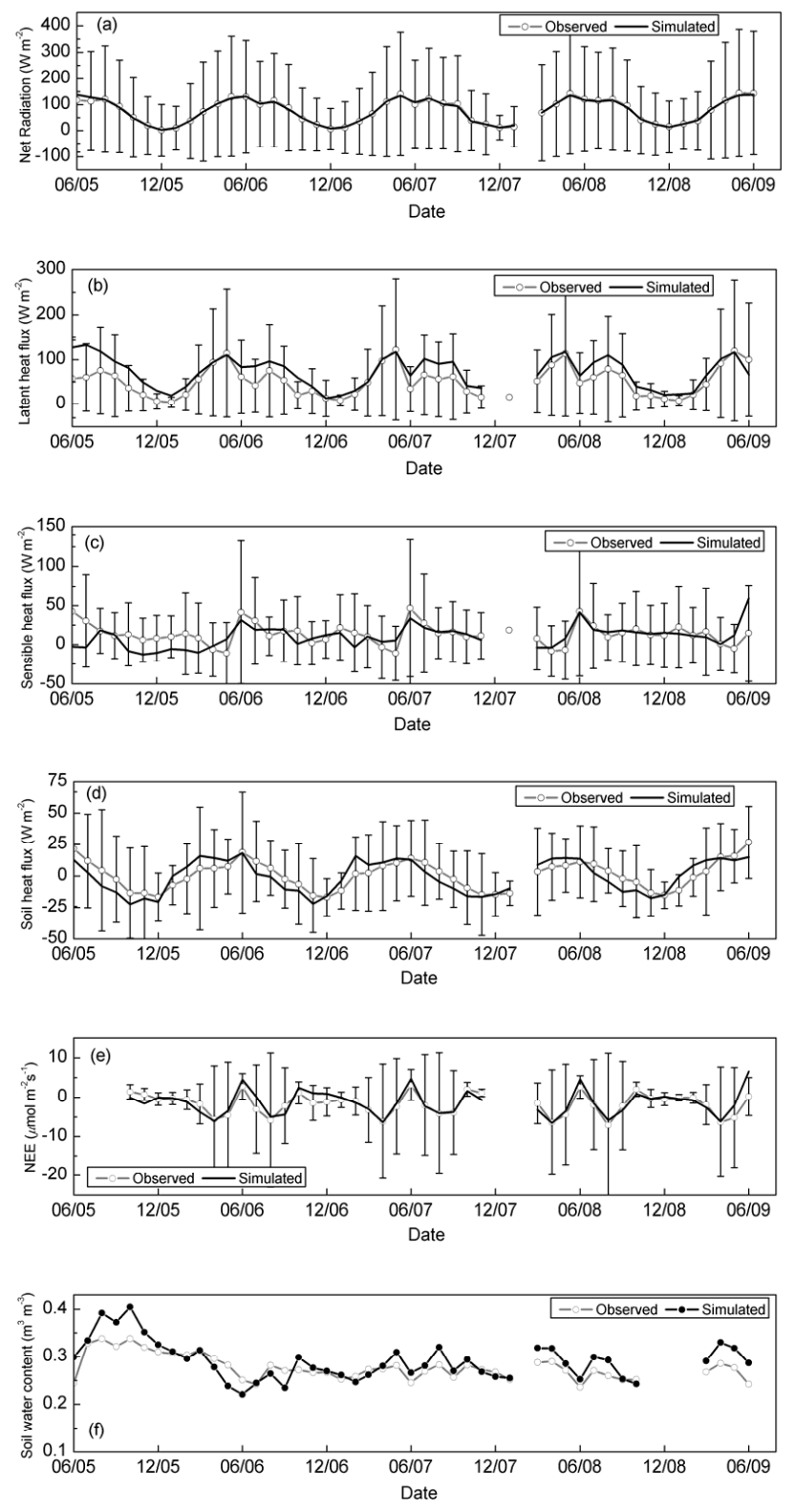

Fig. 4. Seasonal variations in observed and simulated monthlyaverage values of (a) net radiation, (b) latent heat flux, (c) sensible heat flux, (d) soil heat flux, (e) net ecosystem exchange (NEE), and (f) volumetric soil water content $(0-80 \mathrm{~cm}$ average) at the Weishan site. Error bars indicate \pm 1 standard deviation from the mean of the observations.

peak LAI was much under-estimated by the monthly NDVI, no significant differences were found between LE resulted from the coupled model and the original SiB2 with a monthly NDVI. However, the ratio of transpiration to ET decreased from $51 \%$ to $46 \%$ when the coupled model was replaced with the original $\mathrm{SiB} 2$, implying that the original $\mathrm{SiB} 2$ may overpredict soil evaporation.
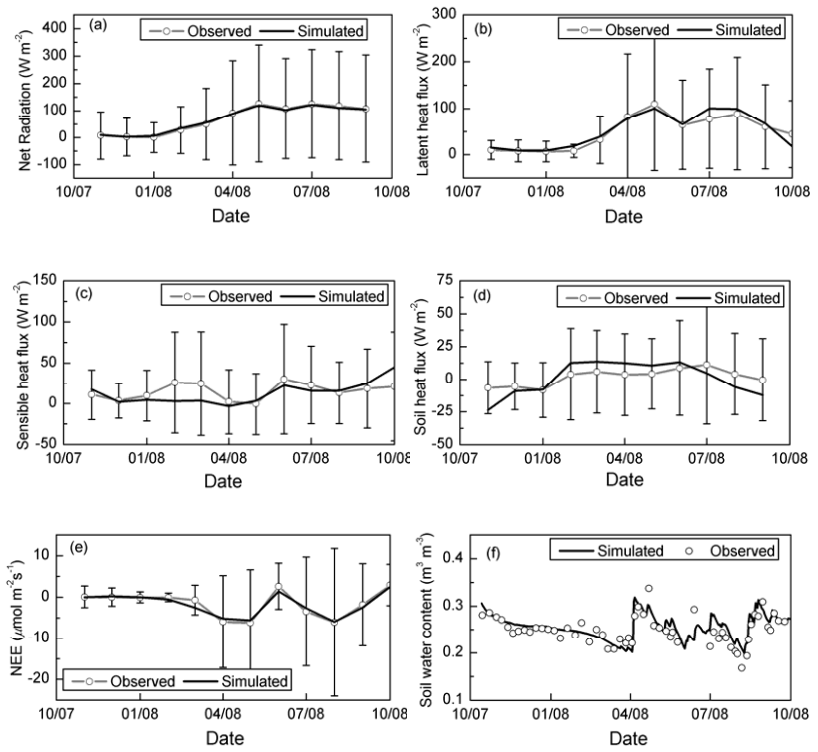

Fig. 5. Seasonal variations in observed and simulated monthlyaverage values of (a) net radiation, (b) latent heat flux, (c) sensible heat flux, (d) soil heat flux, (e) net ecosystem exchange (NEE), and (f) daily-average volumetric soil water content $(0-100 \mathrm{~cm}$ average) at the Luancheng site. Error bars indicate \pm 1 standard deviation from the mean of the observations.

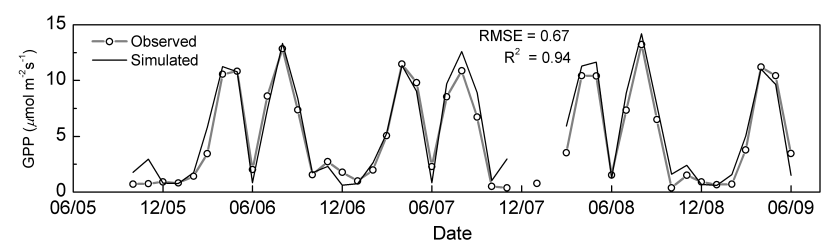

Fig. 6. Simulated and observed monthly-average gross primary production (GPP) at the Weishan site.

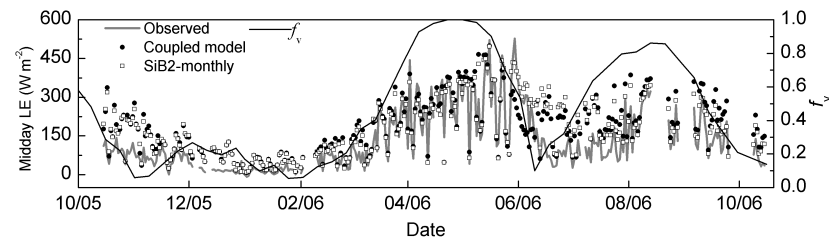

Fig. 7. Midday (10:00-14:00 LT) averaged latent heat flux (LE) from 15 October 2005 to 15 October 2006 at Weishan site. Vegetation cover $\left(f_{\mathrm{V}}\right)$ was also presented.

\subsection{Sensitivity to irrigation amount}

Figure 8 shows the simulated SWC in the root-zone in different irrigation amounts. By converting the biomass carbon in the products (by multiplying by 2.2 ) to biomass and considering a water content of about $14 \%$ in the wheat kernel, we estimated approximately the crop yield which was listed in 
Table 5. Results for the comparisons of the coupled model and the original SiB2 using eight-day NDVI (SiB2-8day) and monthly NDVI (SiB2-monthly) as input. The wheat season was from 15 October to 14 June, and maize season was from 15 June to 14 October.

\begin{tabular}{|c|c|c|c|c|c|}
\hline Variable & Site & Period & $R^{2}$ & RMSE & $\beta^{*}$ \\
\hline \multirow[t]{16}{*}{ Latent heat flux $\left(\mathrm{W} \mathrm{m}^{-2}\right)$} & Weishan & \multicolumn{4}{|l|}{ Wheat season } \\
\hline & & Coupled model & 0.83 & 40.8 & 0.89 \\
\hline & & SiB2-8day & 0.84 & 40.4 & 0.89 \\
\hline & & SiB2-monthly & 0.85 & 39.5 & 0.93 \\
\hline & & \multicolumn{4}{|l|}{ Maize season } \\
\hline & & Coupled model & 0.72 & 69.9 & 1.14 \\
\hline & & SiB2-8day & 0.73 & 61.6 & 1.08 \\
\hline & & SiB2-monthly & 0.69 & 69.5 & 1.10 \\
\hline & Luancheng & \multicolumn{4}{|l|}{ Wheat season } \\
\hline & & Coupled model & 0.85 & 35.6 & 0.78 \\
\hline & & SiB2-8day & 0.76 & 44.9 & 0.67 \\
\hline & & SiB2-monthly & 0.85 & 36.0 & 0.76 \\
\hline & & \multicolumn{4}{|l|}{ Maize season } \\
\hline & & Coupled model & 0.84 & 45.5 & 1.01 \\
\hline & & SiB2-8day & 0.84 & 45.8 & 1.00 \\
\hline & & SiB2-monthly & 0.81 & 54.5 & 1.05 \\
\hline \multirow{16}{*}{$\begin{array}{l}\text { Net ecosystem exchange } \\
\left(\mu \mathrm{mol} \mathrm{m}{ }^{-2} \mathrm{~s}^{-1}\right)\end{array}$} & Weishan & \multicolumn{4}{|l|}{ Wheat season } \\
\hline & & Coupled model & 0.79 & 4.1 & 0.91 \\
\hline & & SiB2-8day & 0.84 & 3.6 & 0.90 \\
\hline & & SiB2-monthly & 0.84 & 3.5 & 0.80 \\
\hline & & \multicolumn{4}{|l|}{ Maize season } \\
\hline & & Coupled model & 0.85 & 4.6 & 0.89 \\
\hline & & SiB2-8day & 0.80 & 5.5 & 0.83 \\
\hline & & SiB2-monthly & 0.74 & 6.3 & 0.86 \\
\hline & Luancheng & \multicolumn{4}{|l|}{ Wheat season } \\
\hline & & Coupled model & 0.78 & 4.7 & 0.88 \\
\hline & & SiB2-8day & 0.76 & 4.9 & 0.86 \\
\hline & & SiB2-monthly & 0.69 & 5.7 & 0.86 \\
\hline & & \multicolumn{4}{|l|}{ Maize season } \\
\hline & & Coupled model & 0.82 & 5.6 & 0.85 \\
\hline & & SiB2-8day & 0.80 & 6.0 & 0.84 \\
\hline & & SiB2-monthly & 0.67 & 8.2 & 0.85 \\
\hline
\end{tabular}

* Slope coefficient of linear regression against the observations.

Table 6 . In cases 6-7 and in reality, the wheat growth was not stressed by soil water because the average SWC was above $0.22 \mathrm{~m}^{3} \mathrm{~m}^{-3}$ at any time in the season. Excess irrigation did not lead to a further increase in ET, Tr, and yield (Table 6), but it percolated into the deeper soil and/or drained as surface runoff. In cases 3-5, soil water stress occurred in the milking stage of wheat, leading to a reduction in ET, Tr, and yield. However, the maximum LAI was slightly reduced because the canopy had been fully developed before the milking stage. In cases 1 and 2, wheat was under moderate soil water stress through jointing stage and flowering stage until maturity, respectively, which led to a significant decrease in ET, Tr, yield, and LAI. The simulated water use efficiency (defined as the ratio of crop yield to total ET) increased with the increase of the irrigation till irrigation reached $122 \mathrm{~mm}$. A further increase in irrigation would not increase the water use efficiency, indicating a waste of water. The sensitivity study showed that the feedbacks among crop growth, ET, yield, and soil water can be reasonably described by the coupled model. 
Table 6. Results of the sensitivity of the model to irrigation amount in the winter wheat season at the Luancheng site (15 October, 2007 to 14 June, 2008). WUE denotes the water use efficiency (Yield/ET).

\begin{tabular}{crrrrrrrr}
\hline Case & $P(\mathrm{~mm})$ & $I^{* *}(\mathrm{~mm})$ & Max. LAI & $\mathrm{SWC}^{*}$ & Yield $\left(\mathrm{g} \mathrm{m}^{-2}\right)$ & $\mathrm{Tr}(\mathrm{mm})$ & $\mathrm{ET}(\mathrm{mm})$ & $\left.\mathrm{WUE}_{(\mathrm{kg} \mathrm{m}}^{-3}\right)$ \\
\hline Reality & 197 & 122 & 6.2 & 0.26 & 663 & 247 & 365 & 1.82 \\
1 & 197 & 0 & 5.2 & 0.18 & 284 & 195 & 311 & 0.91 \\
2 & 197 & 20 & 6.0 & 0.19 & 347 & 213 & 327 & 1.06 \\
3 & 197 & 60 & 6.2 & 0.22 & 547 & 236 & 349 & 1.57 \\
4 & 197 & 80 & 6.2 & 0.24 & 610 & 242 & 356 & 1.71 \\
5 & 197 & 100 & 6.2 & 0.25 & 644 & 246 & 361 & 1.78 \\
6 & 197 & 140 & 6.2 & 0.27 & 665 & 247 & 365 & 1.82 \\
7 & 197 & 240 & 6.2 & 0.28 & 668 & 247 & 366 & 1.82 \\
8 & 197 & 300 & 6.2 & 0.28 & 668 & 247 & 366 & 1.83 \\
\hline
\end{tabular}

* Averaged from 4 April to 10 June for the root zone;

*** irrigation was all implemented in 4 April 2008.

Table 7. Simulated impact of increased atmospheric concentration of $\mathrm{CO}_{2}$ at the Luancheng site. Values in the parentheses are relative changes to the current $\left[\mathrm{CO}_{2}\right]$ level.

\begin{tabular}{lllllll}
\hline Crop & {$\left[\mathrm{CO}_{2}\right]$} & $\begin{array}{l}\text { Max. } \\
\text { LAI }\end{array}$ & $\begin{array}{l}\text { Root-zone } \\
\text { SWC }\end{array}$ & $\begin{array}{l}\text { Total biomass } \\
\text { carbon }\left(\mathrm{g} \mathrm{m}^{-2}\right)\end{array}$ & $\begin{array}{l}\mathrm{Tr} \\
(\mathrm{mm})\end{array}$ & $\begin{array}{l}\text { ET } \\
(\mathrm{mm})\end{array}$ \\
\hline Wheat $^{* *}$ & $381 \mathrm{ppm}^{*}$ & 6.2 & 0.253 & 688 & 247 & 365 \\
& $762(2 \times 381) \mathrm{ppm}$ & $8.6(39 \%)$ & $0.257(2 \%)$ & $980(42 \%)$ & $233(-6 \%)$ & $346(-5 \%)$ \\
& $1143(3 \times 381) \mathrm{ppm}$ & $9.6(55 \%)$ & $0.259(2 \%)$ & $1093(59 \%)$ & $211(-15 \%)$ & $327(-10 \%)$ \\
Maize*** & $381 \mathrm{ppm}^{*}$ & 5.4 & 0.261 & 682 & 210 & 326 \\
& $762(2 \times 381) \mathrm{ppm}$ & $5.6(4 \%)$ & $0.272(4 \%)$ & $703(3 \%)$ & $186(-11 \%)$ & $309(-5 \%)$ \\
& $1143(3 \times 381) \mathrm{ppm}$ & $5.7(6 \%)$ & $0.280(7 \%)$ & $708(4 \%)$ & $175(-17 \%)$ & $303(-7 \%)$ \\
\hline
\end{tabular}

$*\left[\mathrm{CO}_{2}\right]$ at the current level.

** period from October 15, 2007 to June 14, 2008.

**** period from June 15, 2008 to October 1, 2008.

\subsection{Sensitivity to $\mathrm{CO}_{2}$ concentration}

In the absence of soil water stress, the changes of ET and SWC with an increase in $\left[\mathrm{CO}_{2}\right]$ result from the trade-off between increased LAI (which was because of enhanced photosynthesis) and decreased leaf conductance (Calvet et al., 1998). Figure 9 presents the root-zone SWC under different prescribed values of $\left[\mathrm{CO}_{2}\right]$ at the Luancheng site. The corresponding seasonal summaries are listed in Table 7. The simulated SWC increased slightly in the wheat season, even though a significant increase in the LAI of wheat was observed because of $\mathrm{CO}_{2}$ fertilization. This is because leaf stomatal closure limited the transpiration, which offset the positive feedback of transpiration to increased LAI. Simulated changes of SWC and ET in the maize season were similar to the results in the wheat season but corresponded to a slight increase in the LAI of maize. Simulated total biomass carbon of $\mathrm{C} 3$ wheat increased significantly by $42 \%$ under the doubled $\left[\mathrm{CO}_{2}\right]$ condition, but the relative change of total biomass carbon from doubled $\left[\mathrm{CO}_{2}\right]$ condition to tripled

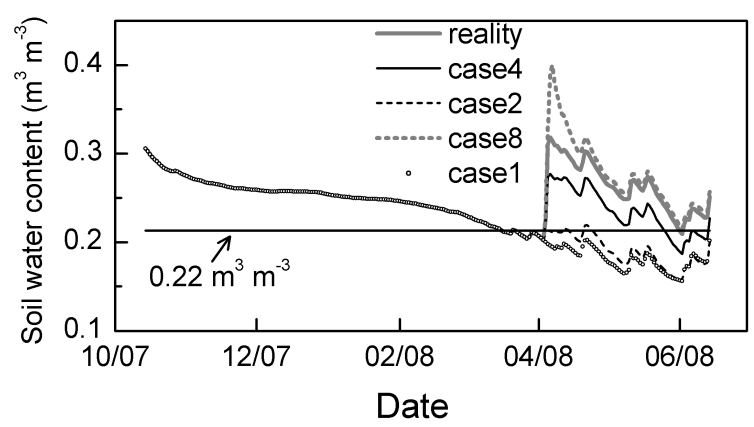

Fig. 8. Simulated root-zone averaged soil water content in different cases. Cases reality, 1, 2, 4, and 8 as given in Table 5, were selected for plotting. The threshold $\left(0.22 \mathrm{~m}^{3} \mathrm{~m}^{-3}\right)$ of incipient soil water stress was also presented.

$\left[\mathrm{CO}_{2}\right]$ condition was significantly lesser. The simulated results were consistent with the experiments which showed that doubling $\left[\mathrm{CO}_{2}\right]$ from 350 to $700 \mathrm{ppm}$ increased wheat 


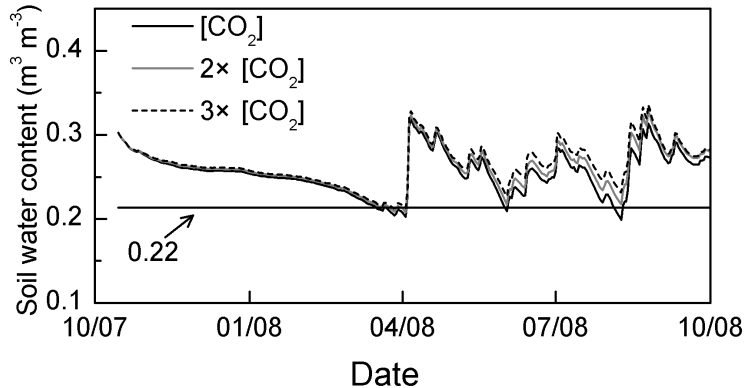

Fig. 9. Simulated root-zone soil water content under different $\mathrm{CO}_{2}$ concentration levels at the Luancheng site. The $\left[\mathrm{CO}_{2}\right]$ denotes $381 \mathrm{ppm}$, and $0.22 \mathrm{~m}^{3} \mathrm{~m}^{-3}$ is the threshold of the incipient water stress.

yield by about $31 \%$, but the effects of $1100-1250 \mathrm{ppm} \mathrm{CO}_{2}$ on wheat yield were lesser than the effects of 600-700 ppm $\mathrm{CO}_{2}$ (Amthor, 2001). On the other hand, both the LAI and the total biomass carbon of maize were unresponsive to the increased $\left[\mathrm{CO}_{2}\right]$ because $\mathrm{CO}_{2}$ contributed nothing or little in the fertilization process of $\mathrm{C} 4$ maize, for the reason that the $\mathrm{C} 4$ photosynthesis is usually saturated at the current $\mathrm{CO}_{2}$ concentration level (Leakey et al., 2006). The simulation results were similar with the modeling work on C3 crops and C4 maize from Calvet et al. (1998).

\section{Conclusions}

The crop phenology and physiology scheme in the SiBcrop model was coupled with the $\mathrm{SiB} 2$ model to estimate phenology, latent heat flux (i.e., ET), and carbon exchange in the winter wheat-summer maize rotation cropping fields in the North China Plain. Two typical EC flux sites with this cropping pattern were used to evaluate the performance of the model. The carbon allocation fractions of product, leaf, stem, and root with the change of GDD in the SiBcrop were substituted with the observations under unlimited soil water condition in this region, and were adjusted to the soil water stress. The seasonal variations in carbon biomass, LAI, energy fluxes, carbon flux, and SWC showed good agreement with the observed values. In particular, simulated latent heat flux and NEE explained the highest variability in their seasonal processes $\left(R^{2}\right.$ for latent heat flux and carbon flux were greater than 0.7). Compared to the original $\mathrm{SiB} 2$ given remotely sensed NDVI as input, the coupled model improved the modeling of crop phenology and carbon flux, especially for the maize. The differences of seasonality of latent heat flux between the coupled model and the original $\mathrm{SiB} 2$ were not significant, but the $\mathrm{SiB} 2$ underestimated the proportion of transpiration to the total ET. Sensitivity analysis showed that the model was sensitive to the irrigation amount and atmospheric $\left[\mathrm{CO}_{2}\right]$, and gave reasonable results. Therefore, the coupled model is capable of simulating the response of ET and crop yield to different irrigation schedules and possible climate changes in this type of agro-ecosystem.

Acknowledgements. This research was supported by the National Natural Science Foundation of China (Project No. 50939004) and the Doctoral Program Foundation of Institutions of Higher Education of China (Project No. 20070003075). We would like to thank two anonymous reviewers whose comments have greatly improved the quality of the manuscript.

Edited by: F. X. Meixner

\section{References}

Amthor, J. S.: Effects of atmospheric $\mathrm{CO}_{2}$ concentration on wheat yield: review of results from experiments using various approaches to control $\mathrm{CO}_{2}$ concentration, Field Crop. Res., 73, 134, 2001.

Arora, V. K. and Boer, G. J.: A parameterization of leaf phenology for the terrestrial ecosystem component of climate models, Glob. Change Biol., 11, 39-59, 2005.

Baker, I., Denning, A. S., Hanan, N., Prihodko, L., Uliasz, M., Vidale, P.-L., Davis, K., and Bakwin, P.: Simulated and observed fluxes of sensible and latent heat and $\mathrm{CO}_{2}$ at the WLEF-TV tower using SiB2.5, Glob. Change Biol., 9, 1262-1277, 2003.

Ball, J. T., Woodrow, I. E., and Berry, J. A.: A model predicting stomatal conductance and its contribution to the control of photosynthesis under different environmental conditions, in: Progress in Photosynthesis Research, edited by: Biggens, J., Martinus Nijhoff, Dordrecht, 221-224, 1987.

Boegh, E., Thorsen, M., and Butts, M. B.: Incorporating remote sensing data in physically based distributed agro-hydrological modeling, J. Hydrol., 287, 279-299, 2004.

Calvet, J., Noilhan, J., Roujean, J., Bessemoulin, P., Cabelguenne, M., Olioso, A., and Wigneron, J.: An interactive vegetation SVAT model tested against data from six contrasting sites, Agr. Forest Meteorol., 92, 73-95, 1998.

Casanova, J. J. and Judge, J.: Estimation of energy and moisture fluxes for dynamic vegetation using coupled SVAT and crop-growth models, Water Resour. Res., 44, W07415, doi:10.1029/2007WR006503, 2008.

Colello, G. D., Grivet, C., Sellers, P. J., and Berry, J. A.: Modeling of energy, water and $\mathrm{CO} 2$ flux in a temperate grassland ecosystem with SiB2: May-October 1987, J. Atmos. Sci., 55, 11411169, 1998.

Collatz, G. J., Ribas-Carbo, M., and Ball, J. A.: Coupled photosynthesis - stomatal conductance model for leaves of C4 plants, Aust. J. Plant Physiol., 19, 519-538, 1992.

Denning, A. S., Collatz, G. J., Zhang, C., David, A. R., Berry, J. A., Sellers, P. J., Collello, G. D., and Dazlich, D. A.: Simulations of terrestrial carbon metabolism and atmospheric $\mathrm{CO}_{2}$ in a general circulation model Part 1: Surface carbon fluxes, Tellus B, 48, 521-542, 1996.

Farquhar, G. D., von Caemmerer, S., and Berry, J. A.: A biochemical model of photosynthetic $\mathrm{CO}_{2}$ assimilation in leaves of $\mathrm{C} 3$ species, Planta, 149, 78-90, 1980.

Gao, Z., Chae, N., Kim, J., Hong, J., Choi, T., and Lee, H.: Modeling of surface energy partitioning, surface temperature, and soil wetness in the Tibetan prairie using the Sim- 
ple Biosphere Model 2 (SiB2), J. Geophys. Res., 109, D06102, doi:10.1029/2003JD004089, 2004.

Gitelson, A. A., Viña, A., Arkebauer, T. J., Rundquist, D. C., Keydan, G., and Leavitt, B.: Remote estimation of leaf area index and green leaf biomass in maize canopies, Geophys. Res. Lett., 30(5), 1148, doi:10.1029/2002GL016450, 2003.

Hanan, N. P., Berry, J. A., Verma, S. B., Walter-Shea, E. A., Suyker, A. E., Burba, G. G., and Denning, A. S.: Testing a model of $\mathrm{CO}_{2}$, water and energy exchange in Great Plains tallgrass prairie and wheat ecosystems, Agric. For. Meteorol., 131, 162-179, 2005.

Ivanov, V. Y., Bras, R. L., and Vivoni, E. R.: Vegetation-hydrology dynamics in complex terrain of semiarid areas: 1. A mechanistic approach to modeling dynamic feedbacks, Water Resour. Res., 44, W03429, doi:10.1029/2006WR005588, 2008.

Kumar, P.: Variability, feedback, and cooperative process dynamics: elements of a unifying hydrologic theory, Geography Compass, 1/6, 1338-1360, 2007.

Leakey, A. D. B., Uribelarrea, M., Ainsworth, E. A., Naidu, S. L., Rogers, A., Ort, D. R., and Long, S. P.: Photosynthesis, productivity, and yield of maize are not affected by open-air elevation of $\mathrm{CO}_{2}$ concentration in the absence of drought, Plant Physiol., 140, 779-790, 2006.

Lei, H.-M. and Yang, D.-W.: Interannual and seasonal variability in evapotranspiration and energy partitioning over an irrigated cropland in the North China Plain, Agr. Forest Meteorol., 158, 581-589, 2010a.

Lei, H.-M. and Yang, D.-W.: Seasonal and interannual variations in carbon dioxide exchange over a cropland in the North China Plain, Glob. Change Biol., 16, 2944-2957, 2010 b.

Liu, C., Zhang, X., and Zhang, Y.: Determination of daily evaporation and evapotranspiration of winter wheat and maize by largescale weighing lysimeter and micro-lysimeter, Agr. For. Meteorol., 111, 109-120, 2002.

Lokupitiya, E., Denning, S., Paustian, K., Baker, I., Schaefer, K., Verma, S., Meyers, T., Bernacchi, C. J., Suyker, A., and Fischer, M.: Incorporation of crop phenology in Simple Biosphere Model (SiBcrop) to improve land-atmosphere carbon exchanges from croplands, Biogeosciences, 6, 969-986, doi:10.5194/bg-6-9692009, 2009.

Maruyama, A. and Kuwagata, T.: Coupling land surface and crop growth models to estimate the effects of changes in the growing season on energy balance and water use of rice paddies, Agi. Forest Meteorol., 150, 919-930, doi:10.1016/j.agrforment.2010.02.011, 2010.

Ministry of Agriculture of China: http://www.moa.gov.cn/zwllm/ sjzl/, last access: April 2010.

Ministry of Water Resources of China: http://www.mwr.gov.cn/ zwzc/hygb/szygb/qgszygb/201001/t20100119_171051.html, access: April 2010.

Mo, X., Liu, S., Lin, Z., Xu, Y., Xiang, Y., and McVicar, T. R.: Prediction of crop yield, water consumption and water use with a SVAT-crop growth model using remotely sensed data on the North China Plain, Ecol. Model., 183, 301-322, 2005.

Monje, O. and Bugbee, B.: Adaptation to high $\mathrm{CO}_{2}$ concentration in an optimal environment: radiation capture, canopy quantum yield and carbon use efficiency, Plant Cell Environ., 21, 315324, 1998.

Moorcroft P. R.: Recent advances in ecosystem-atmosphere interactions: an ecological perspective, Proc. R. Soc. Lond. B., 270,
1215-1227, 2003.

Niklaus, P. A., Glöckler, E., Siegwolf, R., and Körner, C.: Carbon allocation in calcareous grassland under elevated $\mathrm{CO}_{2}$ : a combined ${ }^{13} \mathrm{C}$ pulse-labelling/soil physical fractionation study, Funct. Ecol., 15, 43-50, 2001.

Pauwels, V. R. N., Verhoest, N. E. C., De Lannoy, G. J. M., Guissard, V., Lucau, C., and Defourny, P.: Optimization of a coupled hydrology-crop growth model through the assimilation of observed soil moisture and leaf area index values using an ensemble Kalman filter, Water Resour. Res., 43, W04421, doi:10.1029/2006WR004942, 2007.

Pitman, A. J.: The evolution of, and revolution in, land surface schemes designed for climate models, Int. J. Climatol., 23, 479510, 2003.

Qiao, Y., Yu, Z., and Driessen P. M.: Quantification of dry matter accumulation and distribution among different organs of winter wheat, Chinese J. Appl. Ecol., 13(5), 543-546, 2002 (in Chinese).

Sellers, P. J., Randall, D. A., Collatz, G. J., Berry, J. A., Field, C. B., Dazlich, D. A., Zhang, C., Collelo, G. D., and Bounoua, L.: A revised land surface parameterization $(\mathrm{SiB} 2)$ for atmospheric GCMs. Part I: model formulation, J. Clim., 9, 676-705, 1996a.

Sellers, P. J., Los, S. O., Tucker, C. J., Justice, C. O., Dazlich, D. A., Collatz, G. J., and Randall, D. A.: A revised land surface parameterization (SiB2) for atmospheric GCMs. Part II: the generation of global fields of terrestrial biophysical parameters from satellite data, J. Clim. 9, 706-737, 1996b.

Shao, C., Chen, J., Li, L., Xu, W., Chen, S., Gwen, T., Xu, J., and Zhang, W.: Spatial variability in soil heat flux at three Inner Mongolia steppe ecosystems, Agr. Forest Meteorol., 148, 14331443, 2008.

Shen, Y., Kondoh, A., Tang, C., Zhang, Y., Chen, J., Li, W., Sakura, Y., Liu, C., Tanaka, T., and Shimada, J.: Measurement and analysis of evapotranspiration and surface conductance of a wheat canopy, Hydrol. Process., 16, 2173-2187, 2002.

Sun, H., Shen, Y., Yu, Q., Flerchinger, G. N., Zhang, Y., Liu, C., and Zhang, X.: Effect of precipitation change on water balance and WUE of the winter wheat-summer maize rotation in the North China Plain, Agr. Water Manage., 97, 1139-1145, doi:10.1016/j.agwat.2009.06.004, 2009.

Suter, D., Frehner, M., Fischer, B. U., Nösberger, J., and Lüscher, A.: Elevated $\mathrm{CO}_{2}$ increases carbon allocation to the roots of Lolium perenne under free-air $\mathrm{CO}_{2}$ enrichment but not in a controlled environment, New Phytol., 154, 65-75, 2002.

Velleman, P. F.: Definition and comparison of robust nonlinear data smoothing algorithms, J. Am. Stat. Assoc., 75, 609-615, 1980.

Wang, J., Yu, Q., and Lee, X.: Simulation of crop growth and energy and carbon dioxide fluxes at different time steps from hourly to daily, Hydrol. Process., 21, 2474-2492, 2007.

Wang, L., Koike, T., Yang, K., Jackson, T. J., Bindlish, R., and Yang, D.: Development of a distributed biosphere hydrological model and its evaluation with the Southern Great Plains Experiments (SGP97 and SGP99), J. Geophys. Res., 114, D08107, doi:10.1029/2008JD010800, 2009.

Webb, E. K., Pearman, G. I., and Leuning, R.: Correction of the flux measurements for density effects due to heat and water vapour transfer, Q. J. Roy. Meteorol. Soc., 106, 85-100, 1980.

Wilhelm, W. W., Ruwe, K., and Schlemmer, M. R.: Comparision of three leaf area index meters in a corn canopy, Crop Sci., 40, 
1179-1183, 2000.

Yang, D., Chen, H., and Lei, H.: Estimation of evapotranspiration using a remote sensing model over agriculture land in the North China Plain, Int. J. Remote Sens., 31(14), 3783-3798, 2010.

Yang, D., Herath, S., and Musiake, K.: Comparison of different distributed hydrological models for characterization of catchment spatial variability, Hydrol. Process., 14, 403-416, 2000.
Zhang, Y., Yu, Z., and Driessen, P. M.: Experimental study of assimilate production, partitioning and translocation among plant organs in summer maize (Zea mays) under various environmental and management conditions, Acta Agronomica Sinica, 28(1), 104-109, 2002 (in Chinese). 